\title{
MLLT10/PICALM Fusion Protein
}

National Cancer Institute

\section{Source}

National Cancer Institute. MLLT10/PICALM Fusion Protein. NCI Thesaurus. Code C99586.

A fusion protein encoded by the MLLT 10/PICALM fusion gene. This protein is comprised of the $\mathrm{N}$-terminal zinc finger domain of protein AF-10 fused to the last 4 amino acids of the phosphatidylinositol-binding clathrin assembly protein. 